\title{
EFFECT OF BED PLANTING ON THE QUANTITY AND QUALITY OF HAY IN DIFFERENT MIXING RATIOS OF VETCH AND BARLEY IN THE NORTH OF IRAN
}

\author{
JILANI, M. ${ }^{1}-$ AJAM NOROUZI, H. ${ }^{{ }^{*}}-$ FARAJI, A. $^{2}$ \\ ${ }^{1}$ Department of Agronomy and Plant Breeding, Gorgan Branch, Islamic Azad University \\ Gorgan, Iran \\ ${ }^{2}$ Golestan Agricultural and Natural Resources Research and Education Center, Agricultural \\ Research, Education and Extension Organization (AREEO), Gorgan, Iran \\ *Corresponding author \\ e-mail:ajamnorozei@yahoo.com \\ (Received $4^{\text {th }}$ Apr 2018; accepted $13^{\text {th }}$ Jun 2018)
}

\begin{abstract}
This study was conducted to investigate the effect of bed planting on the quantity and quality of forage yield of vetch and barley in different crop mixing ratios. The field experiment was conducted in 2014-2015 and 2015-2016 on the paddy fields of the North of Iran (Rasht, Guilan Province) as a factorial analysis in randomized complete block design (RCBD) with three replications. The experimental treatments included bed planting at 2 levels (1. rice bran with bed planting and 2. without bed planting as control) and crop mixing at 6 levels (1. Sole vetch, 2. Sole barley, 3. $20 \%$ vetch to $80 \%$ of barley, $4.40 \%$ vetch to $60 \%$ of barley, $5.60 \%$ vetch to $40 \%$ of barley, $6.25 \%$ vetch to $75 \%$ barley as replacement ratio of crop mixing). The recorded data were the followings: forage yield, crude protein yield and quality traits like crude protein (CP), dry matter digestibility (DMD), and acid detergent fiber (ADF), neutral detergent fiber (NDF). Mixed cropping indices were calculated by means of land equivalent ratio (LER) and Money advantages index (MAI). Results showed that rice bran with bed planting affects some quantity and quality traits of forage. Among mixing ratios, planting of $40 \%$ barley and $60 \%$ additive vetch had highest forage yield. Additive mixing ratios had the highest crude protein yield among mixing ratios. According to the results, in the North of Iran the highest LER and forage yield was obtained from rice bran with bed planting and $40 \%$ additive of vetch to barley.
\end{abstract}

Keywords: forage yield, crude protein yield, money advantage index, dry matter digestibility, land equivalent ratio

\section{Introduction}

During the post rainy season (October-March) in the sub-humid region of northern Iran, average cumulative evapotranspiration and runoff are high. Therefore, the low status of soil moisture in the root zone usually limits productivity of rainfed winter crops in this region. Conserving moisture that has accumulated in the root zone during the previous rainy season can increase productivity of rainfed winter crops in the dry season. Soil management practices can influence conservation and efficiency of stored water (Sarkar and Singh, 2007). Applying mulch on the soil surface to reduce evaporation rate and discourage weeds is another water conservation practice in India (Sarkar and Singh, 2007).

Mixed cropping as method crop intensification is commonly practiced in densely populated countries to provide more food. Mixed cropping of annual cereals and pulse crop is commonly practiced in humid topic regions because total seed production generally enhanced compared with sole cropping (Ciftci and Ulker, 2005). The legumegrass combination has been used in several mixed cropping systems including forage 
and cover crops (Ramos et al., 2011). Generally, grasses in mixed cropping with legumes take more $\mathrm{N}$ than in sole cropping, because of transfer from rhizodeposit- $\mathrm{N}$ of legume to the associated grass (Rasmussen et al., 2007).

Vetch is one of popular pulse crops of Iran and is an annual leguminous crop which produces high-quality forage and can be cultivated in most climates as rainfed or irrigated, but grows best in temperate and cold-temperate conditions. In recent years, vetch and grass pea cultivation has drawn much attention as a crop well-adapted to harsh conditions and arid and semi-arid regions, with high protein content (Habibi et al., 2010). The different Vicia species are used as direct grazing and also for their green forage, hay and seed (Lanyasunya et al., 2007). In studies of Lanyasunya et al. (2007), the $\mathrm{CP}, \mathrm{Ca}$ and $\mathrm{P}$ contents of common vetch (Vicia sativa L.) has shown to be 18.4, 0.132 and $0.34 \%$ on a dry weight basis, respectively, with $59 \%$ total digestible nutrients. In north of Iran, farmers prefer planting of vetch with cereals like barley over pure planting of them. Their mixture can be considered as feed for animals during winter or early spring.

Sowing a forage crop in rotation with cereals, is a highly effective method for, for example, soil properties reclamation (MeVay et al., 1989) and increasing rainwater infiltration in soils (Daniel et al., 2006). The high ability of forage legumes for nitrogen fixation is among their most important characters that can reduce need for applying chemical nitrogen fertilizers with implementing them in farming rotations (Rao et al., 2005). Kusmiyati et al. (2013) reported that application of 3 and 6 ton/ha mulch increased plant growth, forage yield and nutritional quality of guinea grass but Plant growth, forage yield and nutritional quality of guinea grass were not affected by monoculture or mixed cropping with Sesbania, however the highest yield was obtained from 6 ton/ha mulch and mix cropping.

Forage grass quality is affected by many factors such as the species, cutting interval, phase of plant development, soil fertility, fertilizer, disease and climatic conditions. It is usually found that the most important factor affecting protein content in herbage dry matter is phase of plant development. Forage quality will decrease, in term of decreasing crude protein and increasing levels of cell wall constituents, with advancing maturity (Kusmiyati et al., 2013).

Various indices such as land equivalent ratio (LER) and monetary advantage index (MAI), have been developed to describe the competition and possible economic advantage in intercropping (Banik et al., 2000; Ghosh, 2004). Mathematical indices can help researchers summarize, interpret, and display the results from plant competition trials (Weigelt and Jolliffe, 2003). Indices can express various attributes of competition in plant communities, including competition intensity, competitive effects, and the outcome of competition. They help in the interpretation of complex data and allow comparison of results from different studies with the use of the same index. Among indices being used for assessing competition between intercrops, land equivalent ratio is the most commonly used for intercrop versus sole crop comparisons (Agegnehu et al., 2006).

One the most important reason for mixed cropping is increasing production per area (Ghosh, 2004). Land Equivalent Ratio (LER) and monetary advantage index (MAI) is used by researchers as an indicator to assess effect of intercropping on land productivity (Mead and Willey, 1980). 
In this study we aim to quantify the effects of different bed planting and mixing ratio treatments on the quantity and quality yield of barley and vetch under rainfed conditions.

\section{Material and methods}

This study was conducted as a factorial experiment in a randomized complete block design with 3 replications in Rice Research Institute of Iran (RRII), located in Rasht (Guilan Province), Iran, during two years, 2014-2015 and 2015-2016. The area is N $37^{\circ}$ $16^{\prime}$ and $\mathrm{E} 041^{\circ} 36^{\prime}$ and $-7 \mathrm{~m}$ above sea level.

Experimental factors included bed planting at 2 levels (1. Rice bran as bed planting and 2. Without bed planting as control) and mix cropping at 6 levels (1. Sole vetch, 2. Sole barley, 3. 20\% Additive of vetch to barley, 4. $40 \%$ Additive of vetch to barley, 5. $60 \%$ Additive of vetch to barley, $6.25 \%$ vetch and $75 \%$ barley as substitutive ratio of mix cropping).

The experimental site was ploughed, harrowed and a basal dose of $100 \mathrm{~kg} \mathrm{NPK} \mathrm{ha}^{-1}$ was broadcast. Seed planting of an Iranian native cultivar of barley (cv. Behrokh) and annual common vetch (cv. Lameie), were evaluated in an intercropping system. Plots consisted of various row numbers depending on intercropping ratios. Planting rows were $0.2 \mathrm{~m}$ wide for both barley and vetch and $5.5 \mathrm{~m}$ long. Plots were seeded on October by hand and two extra rows on the border of each cropping pattern were considered as guard rows. Four meters of all rows within each plot were hand-harvested on 4th of May. Rice bran as bed planting was applied by hand-spreading at the rate of $50 \mathrm{~kg}$ per hectare to form an approximately $20 \mathrm{~mm}$ thick layer between crop rows. Bed planting treatments were imposed before sowing.

After oven drying at $72^{\circ}$ for $48 \mathrm{~h}$, herbage dry yield was determined. To determine the influences of $\mathrm{N}$ and seeding rate on forage quality, a 200-g sample was taken and grounded to pass through a 1-mm sieve. Near-infrared spectroscopy (NIR) (Inframatic 8600 , Perten Instruments) was used to determine forage quality indices, including crude protein (CP), dry matter digestibility (DMD), and acid detergent fiber (ADF) neutral detergent fiber (NDF). Before using NIR, forage quality indices of one replication (using three subsamples) of each treatment was determined using wet chemistry methods as described below. These were further used to calibrate NIR (Jafari et al., 2003).

Relative feed value (RFV) was identified and formulated by Van Dyke and Anderson (2002). All formulas are indicated below:

$$
\begin{gathered}
\mathrm{DDM}=88.9-(0.77 \times \mathrm{ADF} \%) \\
\mathrm{DMI}=(120 / \mathrm{NDF} \%) \\
\mathrm{RFV}=\mathrm{DDM} \% \times \mathrm{DMI} \% \times 0.775 \\
\mathrm{NE} 1=((1.044-(0.0119) \times \mathrm{ADF} \%)) \times 2.205
\end{gathered}
$$

where DDM was digestible dry matter as percentage (\%) of dry matter, and DMI was dry matter intake as percentage (\%) of body weight. 
The measure used to estimate effectiveness and profitability of inter-or mixed cropping is Land Equivalent Ratio (LER), which is calculated as (Mead and Willey, 1980):

$$
\mathrm{LER}=\mathrm{Y}_{\mathrm{ij}} / \mathrm{Y}_{\mathrm{ii}}+\mathrm{Y}_{\mathrm{ji}} / \mathrm{Y}_{\mathrm{jj}}
$$

where:

Yii and $Y j j=$ Yields of $i$ and $j$ species in their sole cropping,

Yij and Yji $=$ Their yield in mixed cropping.

When LER measures 1.0, it indicates that the mixed cropping and sole cropping have yield equivalence, LERs above 1.0 indicate advantages of mixed cropping and LERs below 1.0 show no real yield advantages from mixed cropping.

The Monetary Advantage Index (MAI) which gives an indication of the economic advantage of the intercropping system was calculated according to Ghosh (2004) as follows:

$$
\mathrm{MAI}=(\text { monetary value of combined intercrops })(\mathrm{LER}-1) / \mathrm{LER} .
$$

Economic values of grain and stover produced were estimated based on the average forage yield of barley (70\$ per ton) and vetch (110\$ per ton).

Data analysis for two years was done using SAS (Ver 9.1). For collation of additive and substitutive mixed cropping we used orthogonal analysis. Analysis of combined experiments was done at the end of two years and means were compared using LSD test at 0.05 probability level. Before statistical analysis.

\section{Results and discussion}

\section{Ash}

There is no difference between additive and replacement of treatment (Table 1). Results showed that without bed planting and $60 \%$ additive to barley $(7.65 \%)$ had higher ash and sole vetch on without bed planting (6.64\%) had lowest ash (Table 2). Among mixtures, the highest Ash values obtained from 25\% vetch and $75 \%$ barley treatment with $7.48 \%$ and sole barley with $7.09 \%$ had lowest ash (Table 2). Alizadeh and Teixeira da silva (2013) reported that pure vetch obtained the lowest ash values and they did not find any differences between of mixture ratios.

\section{Water soluble carbohydrates (WSC)}

There were no significant differences in the two-year and orthogonal average values of WSC (Table 2). The results showed that bed planting and mixing ratios had significant effect on WSC and without rice bran treatment had higher amount of WSC. Among mixing ratios, sole vetch had higher WSC and sole barley had the lowest WSC (Table 2). Dahmardeh et al (2009) noted that WSC concentration increased in intercrops compared with in the sole cowpea.

\section{Neutral detergent fiber (NDF) and acid detergent fiber (ADF)}

Other important quality characteristics for forages are the concentrations of NDF and ADF (Assefa and Ledin, 2001). In this experiment a similar trend to that of CP content 
was observed for NDF, it increased as the common vetch seeding proportion increased in mixtures (Table 2). The $25 \%$ vetch and $75 \%$ barley $(33.49 \%$ ) as well as vetch monoculture $(32.90 \%)$ had the lowest value of NDF, whereas the highest value was observed in monoculture barley (36.97\%). This result like most other studies (Caballero et al., 1995; Assefa and Ledin, 2001).

Table 1. Results of analysis of variance and $F$ values of some evaluate traits of barley and vetch in pure stand and its mixtures at different bed planting in two years

\begin{tabular}{c|c|c|c|c|c|c|c}
\hline S.O.V. & df & Ash & WSC & ADF & NDF & DMD & TDN \\
\hline Orthogonal & 1 & $0.001 \mathrm{~ns}$ & $0.21 \mathrm{~ns}$ & $4.31 \mathrm{~ns}$ & $9.88^{* *}$ & $10.53 * *$ & $7.14 \mathrm{~ns}$ \\
Year & 1 & $1.37 * *$ & $0.43 \mathrm{~ns}$ & $5.55 \mathrm{~ns}$ & $0.49 \mathrm{~ns}$ & $15.7 *$ & $9.22 \mathrm{~ns}$ \\
R (Year) & 4 & 3.74 & 54.76 & 0.03 & 52.5 & 0.94 & 0.05 \\
Bed Planting (BP) & 1 & $0.11 \mathrm{~ns}$ & $104.1 * *$ & $0.08 \mathrm{~ns}$ & $14.7 \mathrm{~ns}$ & $1.08 \mathrm{~ns}$ & $0.13 \mathrm{~ns}$ \\
Mixing Ratios (MR) & 5 & $0.38 *$ & $11.07 * *$ & $6.37 * *$ & $37.6 * *$ & $22.8 * *$ & $10.6 * *$ \\
BP * MR & 5 & $0.89 * *$ & $43.73 * *$ & $4.62 *$ & $16.0 *$ & $3.44 \mathrm{~ns}$ & $7.71 *$ \\
Year * BP & 1 & $0.40 \mathrm{~ns}$ & $1.82 \mathrm{~ns}$ & $0.02 \mathrm{~ns}$ & $0.21 \mathrm{~ns}$ & $0.37 \mathrm{~ns}$ & $0.02 \mathrm{~ns}$ \\
Year * MR & 5 & $0.04 \mathrm{~ns}$ & $0.21 \mathrm{~ns}$ & $0.02 \mathrm{~ns}$ & $0.20 \mathrm{~ns}$ & $0.24 \mathrm{~ns}$ & $0.04 \mathrm{~ns}$ \\
Year * BP * MR & 5 & $0.06 \mathrm{~ns}$ & $0.94 \mathrm{~ns}$ & $0.03 \mathrm{~ns}$ & $0.17 \mathrm{~ns}$ & $0.30 \mathrm{~ns}$ & $0.0-3 \mathrm{~ns}$ \\
Error & 44 & 0.14 & 1.27 & 1.67 & 4.79 & 2.27 & 2.78 \\
CV $(\%)$ & & 5.12 & 6.48 & 3.11 & 6.23 & 2.66 & 3.50 \\
\hline
\end{tabular}

** and $*$, respectively, significant in $1 \%$ and $5 \%$ level

The concentrations of acid detergent fibers were not affected by year and orthogonal (Table 1). Among mixing ratio treatments, $60 \%$ additive vetch to barley produced statistically maximum ADF (42.23 g. $\mathrm{kg}^{-1}$ ) and the minimum ADF values obtained from $25 \%$ vetch to $75 \%$ barley with average of 40.54 g.kg ${ }^{-1}$ (Table 2).

Kocer and Albayrak (2012) noted that sole pea had lowest ADF and NDF concentration. Aasen et al (2004) reported that increasing the legume proportion resulted in decreased ADF and NDF concentrations for the legume-grass mixtures. Carr et al. (2004) found that pea, barley, oat, pea-barley and pea-oat mixtures of ADF values $38.2 \%, 38.5 \%, 34.4 \%$ and $36.5 \%$, respectively. Strydhorst et al. (2008) reported that barley and pea-barley mixtures of NDF values were $55.2 \%$ and $41.8 \%$, respectively. Van Soest (1996) indicated that under similar growth conditions, legumes have low NDF values whereas cereals have high values which are in agreement with the present study.

\section{Dry matter digestibility $($ DMD $)$}

There were no significant differences in DMD among the Bed planting factors. However, there were significant differences between orthogonal and mixture ratios (Table 1). Without bed planting had higher DMD (Table 2). Among mixture ratios, the highest DMD was obtained from sole vetch (58.49 $\left.\mathrm{g} \cdot \mathrm{kg}^{-1}\right)$ and lower DMD was shown from monoculture barley (55.16 g. $\mathrm{kg}^{-1}$ ). Sadeghpour et al. (2014) reported that annual medic sole culture had higher DMD than barley and mixture of barley with annual medic therefore decreased DMD of the mixed forage. 
Table 2. Mean of some evaluate traits of barley and vetch in pure stand and its mixtures at different bed planting in two years

\begin{tabular}{|c|c|c|c|c|c|c|}
\hline Year & Ash & WSC & $\operatorname{ADF}\left(\mathrm{g} \mathrm{kg}^{-1}\right)$ & NDF $\left(\mathrm{g} \mathrm{kg}^{-1}\right)$ & DMD $\left(\mathrm{g} \mathrm{kg}^{-1}\right)$ & TDN $\left(\mathrm{g} \mathrm{kg}^{-1}\right)$ \\
\hline $2014-2015$ & $7.48 \mathrm{a}$ & $17.32 \mathrm{a}$ & $41.87 \mathrm{a}$ & $35.05 \mathrm{a}$ & $57.05 \mathrm{a}$ & $47.34 \mathrm{a}$ \\
\hline 2015-2016 & $7.21 \mathrm{~b}$ & $17.47 \mathrm{a}$ & $41.31 \mathrm{a}$ & $35.21 \mathrm{a}$ & $56.12 \mathrm{~b}$ & $48.06 \mathrm{a}$ \\
\hline \multicolumn{7}{|l|}{ Orthogonal } \\
\hline Additive ratio & $7.45 \mathrm{a}$ & $17.12 \mathrm{a}$ & $42.14 \mathrm{a}$ & $35.81 \mathrm{a}$ & $56.0 \mathrm{~b}$ & $47.0 \mathrm{a}$ \\
\hline Replacement ratio & $7.48 \mathrm{a}$ & $16.61 \mathrm{a}$ & $40.54 \mathrm{a}$ & $33.49 \mathrm{~b}$ & $57.41 \mathrm{a}$ & $49.06 \mathrm{a}$ \\
\hline \multicolumn{7}{|l|}{ Bed planting (BP) } \\
\hline $\begin{array}{l}\text { Without rice bran } \\
\text { (control) (BP1) }\end{array}$ & $7.38 \mathrm{a}$ & $18.60 \mathrm{a}$ & $41.56 \mathrm{a}$ & $35.58 \mathrm{a}$ & $56.71 \mathrm{a}$ & $47.74 \mathrm{a}$ \\
\hline $\begin{array}{l}\text { Rice bran bed planting } \\
(\mathrm{BP} 2)\end{array}$ & $7.30 \mathrm{a}$ & $16.19 \mathrm{~b}$ & $41.62 \mathrm{a}$ & $34.68 \mathrm{a}$ & $56.46 \mathrm{a}$ & $47.66 \mathrm{a}$ \\
\hline \multicolumn{7}{|l|}{ Mixing ratios (MR) } \\
\hline Sole vetch (MR1) & $7.14 \mathrm{bc}$ & $18.60 \mathrm{a}$ & $40.82 \mathrm{bc}$ & $32.90 \mathrm{c}$ & $58.49 \mathrm{a}$ & $48.69 \mathrm{ab}$ \\
\hline Sole barley (MR2) & $7.09 \mathrm{c}$ & $17.82 \mathrm{a}$ & $41.77 \mathrm{ab}$ & $36.97 \mathrm{a}$ & $55.16 \mathrm{c}$ & $47.47 \mathrm{bc}$ \\
\hline $\begin{array}{l}20 \% \text { additive vetch to } \\
\text { barley (MR3) }\end{array}$ & $7.47 \mathrm{a}$ & $17.71 \mathrm{a}$ & $42.18 \mathrm{a}$ & $36.03 \mathrm{ab}$ & $55.86 \mathrm{c}$ & $46.94 \mathrm{c}$ \\
\hline $\begin{array}{c}40 \% \text { additive vetch to } \\
\text { barley (MR4) }\end{array}$ & $7.46 \mathrm{a}$ & $17.72 \mathrm{a}$ & $42.0 \mathrm{a}$ & $36.96 \mathrm{a}$ & $56.34 \mathrm{bc}$ & $47.17 \mathrm{c}$ \\
\hline $\begin{array}{c}60 \% \text { additive vetch to } \\
\text { barley (MR5) }\end{array}$ & $7.42 \mathrm{ab}$ & $15.93 \mathrm{~b}$ & $42.23 \mathrm{a}$ & $34.44 \mathrm{bc}$ & $55.80 \mathrm{c}$ & $46.88 \mathrm{c}$ \\
\hline $\begin{array}{c}25 \% \text { vetch and } 75 \% \\
\text { barley (MR6) }\end{array}$ & $7.48 \mathrm{a}$ & $16.61 \mathrm{~b}$ & $40.54 \mathrm{c}$ & $33.49 \mathrm{c}$ & $57.41 \mathrm{c}$ & $49.06 \mathrm{a}$ \\
\hline \multicolumn{7}{|l|}{$\mathbf{B P} * \mathbf{M R}$} \\
\hline $\mathrm{BP} 1 * \mathrm{MR} 1$ & $6.64 \mathrm{~d}$ & $18.82 \mathrm{~b}$ & $40.44 \mathrm{de}$ & $33.70 \mathrm{~cd}$ & $59.42 \mathrm{a}$ & $49.18 \mathrm{ab}$ \\
\hline $\mathrm{BP} 1 * \mathrm{MR} 2$ & $7.30 \mathrm{abc}$ & $16.75 \mathrm{~d}$ & $41.46 \mathrm{bcd}$ & $38.60 \mathrm{a}$ & $55.57 \mathrm{def}$ & $47.86 \mathrm{bcd}$ \\
\hline $\mathrm{BP} 1 * \mathrm{MR} 3$ & $7.61 \mathrm{a}$ & $17.10 \mathrm{~cd}$ & $42.70 \mathrm{ab}$ & $36.47 \mathrm{ab}$ & $55.29 \mathrm{def}$ & $46.26 \mathrm{de}$ \\
\hline BP1 * MR4 & $7.52 \mathrm{ab}$ & $21.04 \mathrm{a}$ & $42.35 \mathrm{abc}$ & $37.43 \mathrm{ab}$ & $55.91 \mathrm{cdef}$ & 46.72 cde \\
\hline $\mathrm{BP} 1 * \mathrm{MR} 5$ & $7.65 \mathrm{a}$ & $18.71 \mathrm{~b}$ & 41.26 cde & $35.53 \mathrm{bc}$ & 56.58 cde & $48.13 \mathrm{abc}$ \\
\hline $\mathrm{BP} 1 * \mathrm{~B} 6$ & $7.58 \mathrm{ab}$ & $19.17 \mathrm{~b}$ & $41.13 \mathrm{cde}$ & $31.77 \mathrm{~d}$ & $57.46 \mathrm{bc}$ & $48.30 \mathrm{abc}$ \\
\hline $\mathrm{BP} 2 * \mathrm{~B} 1$ & $7.64 \mathrm{a}$ & $18.39 \mathrm{~b}$ & $41.20 \mathrm{cde}$ & $32.10 \mathrm{~d}$ & $58.46 \mathrm{ab}$ & $48.20 \mathrm{abc}$ \\
\hline $\mathrm{BP} 2 * \mathrm{~B} 2$ & $6.88 \mathrm{~cd}$ & $18.88 \mathrm{~b}$ & $42.07 \mathrm{abc}$ & $35.33 \mathrm{bc}$ & $54.73 \mathrm{f}$ & $47.08 \mathrm{cde}$ \\
\hline $\mathrm{BP} 2 * \mathrm{~B} 3$ & $7.32 \mathrm{ab}$ & $18.31 \mathrm{bc}$ & $41.66 \mathrm{bcd}$ & $35.60 \mathrm{bc}$ & 56.43 cde & $47.61 \mathrm{bcd}$ \\
\hline $\mathrm{BP} 2 * \mathrm{~B} 4$ & $7.41 \mathrm{ab}$ & $14.40 \mathrm{e}$ & $41.64 \mathrm{bcd}$ & $36.48 \mathrm{ab}$ & $56.76 \mathrm{~cd}$ & $47.63 \mathrm{bcd}$ \\
\hline $\mathrm{BP} 2 * \mathrm{~B} 5$ & $7.19 \mathrm{bc}$ & $13.14 \mathrm{f}$ & $43.20 \mathrm{a}$ & $33.35 \mathrm{~cd}$ & 55.03 ef & $45.62 \mathrm{e}$ \\
\hline $\mathrm{BP} 2 * \mathrm{~B} 6$ & $7.39 \mathrm{ab}$ & $14.05 \mathrm{ef}$ & $39.95 \mathrm{e}$ & $35.22 \mathrm{bc}$ & $57.36 \mathrm{dc}$ & $49.82 \mathrm{a}$ \\
\hline
\end{tabular}

*Values within a column followed by the same letter are not significantly different at LSD $(\mathrm{P} \leq 0.05)$

\section{Total digestible nutrients (TDN)}

The TDN refers to the nutrients that are available for livestock and are related to the ADF concentration of the forage and, as percentage of ADF increases, TDN declines (Albayrak et al., 2011). The results showed that mixing ratios and interaction of mixing 
ratios and bed planting had effects on TDN. Among mixing ratios, $75 \%$ barley and $25 \%$ vetch $\left(49.06 \mathrm{~g} . \mathrm{kg}^{-1}\right)$ and $20 \%$ additive vetch to barley $\left(46.94 \mathrm{~g} \cdot \mathrm{kg}^{-1}\right)$ had the highest and lowest TDN values respectively. Kocer and Albayrak (2012) reported that Pea-oat and pea-barley mixtures ratios had more TDN values than monoculture oat and barley monoculture. They noted that the TDN refers to the nutrients that are available for livestock and are related to the ADF concentration of the forage.

\section{Relative feed value (RFV)}

Forage nutritive value, as indicated by the RFV, was improved in all legume-barley mix cropping relative to the sole barley crop (Table 3). The lower barley sole crop RFV was attributed to the higher NDF and ADF concentrations in the sole crop barley. Carr et al (2004) reported higher NDF concentrations in sole crop barley relative to peabarley intercrops of the legume-barley intercrops, Sole vetch had the highest RFV (168.7\%), while sole barley had the lowest RFV (139.3\%). Differences in RFV of legume and barley were attributed to differences in NDF, as ADF was similar between legume and barley.

Table 3. Results of analysis of variance and $F$ values of some evaluate traits of barley and vetch in pure stand and its mixtures at different bed planting in two years

\begin{tabular}{c|c|c|c|c|c|c}
\hline S.O.V. & df & RFV & NEI & CP & Forage yield & Crude protein yield (CPY) \\
\hline Orthogonal & 1 & $2871.3^{* *}$ & $0.32^{*}$ & $13.35 \mathrm{~ns}$ & $3555111 \mathrm{~ns}$ & $4552.6 \mathrm{~ns}$ \\
Year & 1 & $199.4^{* *}$ & $0.466^{*}$ & $39.26^{* *}$ & $151617 \mathrm{~ns}$ & $4545417.5^{*}$ \\
R (Year) & 4 & 933.8 & 0.03 & 6.30 & 1377456 & 59088.6 \\
Bed planting (BP) & 1 & $163.7 \mathrm{~ns}$ & $0.03 \mathrm{~ns}$ & $2.89 \mathrm{~ns}$ & $14311250^{* *}$ & $260184.9 \mathrm{~ns}$ \\
Mixing ratios (MR) & 5 & $1593.8^{* *}$ & $0.66^{* *}$ & $75.33^{* *}$ & $62953463^{* *}$ & $1088928^{* *}$ \\
BP * MR & 5 & $250.4^{*}$ & $0.1 \mathrm{~ns}$ & $4.36 \mathrm{~ns}$ & $1271474 \mathrm{~ns}$ & $70233.2 \mathrm{~ns}$ \\
Year * BP & 1 & $0.39 \mathrm{~ns}$ & $0.009 \mathrm{~ns}$ & $1.0 \mathrm{~ns}$ & $4966 \mathrm{~ns}$ & $7474.6 \mathrm{~ns}$ \\
Year* MR & 5 & $2.36 \mathrm{~ns}$ & $0.007 \mathrm{~ns}$ & $0.46 \mathrm{~ns}$ & $192575 \mathrm{~ns}$ & $25394.6 \mathrm{~ns}$ \\
Year * BP * MR & 5 & $8.1 \mathrm{~ns}$ & $0.009 \mathrm{~ns}$ & $1.54 \mathrm{~ns}$ & $270275 \mathrm{~ns}$ & $25669.6 \mathrm{~ns}$ \\
Error & 44 & 106.9 & 0.066 & 5.50 & 1157305 & 10599.2 \\
CV (\%) & & 6.84 & 3.37 & 14.26 & 11.47 & 20.91 \\
\hline
\end{tabular}

** and $*$, respectively, significant in $1 \%$ and $5 \%$ level

As expected, RFV values are positively correlated with NDF and ADF contents since they are functions of each other. The highest RFV was determined in the pure stand of common vetch while the lowest RFV was observed in the pure stand of barley (Table 4).

Van Soest (1996) reported that the RFV is not a direct measure of the nutritional content of forage, but that it is important for estimating the value of the forage. The $\mathrm{RFV}$ is an index that is used to predict the intake and energy value of the forages and it is derived from the DDM and DMI. Forage with an RFV value $>151$ is considered prime (Horrocks and Vallentine, 1999). In the present experiments, the RFV values of most treatments was higher than 151 and it showed high quality of forage production in north of Iran. 
Table 4. Mean of some evaluate traits of barley and vetch in pure stand and its mixtures at different bed planting in two years

\begin{tabular}{|c|c|c|c|c|c|}
\hline Year & RFV (\%) & $\begin{array}{c}\text { NEl } \\
\left(\text { Mcal.kg }^{-1}\right)\end{array}$ & $\mathrm{CP}(\%)$ & $\begin{array}{c}\text { Forage } \\
\text { yield } \\
\left(\text { kg.ha }^{-1}\right)\end{array}$ & $\begin{array}{c}\text { Crude protein } \\
\text { yield (CPY) } \\
\left(\mathrm{kg} . h a^{-1}\right)\end{array}$ \\
\hline $2014-2015$ & $152.8 \mathrm{a}$ & $7.70 \mathrm{a}$ & $17.18 \mathrm{a}$ & $9717 \mathrm{a}$ & $1633.9 \mathrm{a}$ \\
\hline $2015-2016$ & $149.5 \mathrm{~b}$ & $7.54 \mathrm{~b}$ & $15.70 \mathrm{~b}$ & $9625 \mathrm{a}$ & $1475.0 \mathrm{~b}$ \\
\hline \multicolumn{6}{|l|}{ Orthogonal } \\
\hline Additive ratio & $146.0 \mathrm{~b}$ & $7.52 \mathrm{~b}$ & $16.04 \mathrm{a}$ & $10934 \mathrm{a}$ & $1756.6 \mathrm{a}$ \\
\hline Replacement ratio & $160.9 \mathrm{a}$ & $7.76 \mathrm{a}$ & $16.25 \mathrm{a}$ & $10275 \mathrm{a}$ & $1680.8 \mathrm{a}$ \\
\hline \multicolumn{6}{|l|}{ Bed planting (BP) } \\
\hline Without rice bran (control) (BP1) & $149.6 \mathrm{a}$ & $7.64 \mathrm{a}$ & $16.63 \mathrm{a}$ & $9225 \mathrm{~b}$ & $1494.3 \mathrm{a}$ \\
\hline Rice bran bed planting (BP2) & $152.6 \mathrm{a}$ & $7.60 \mathrm{a}$ & $16.24 \mathrm{a}$ & $10117 \mathrm{a}$ & $1614.5 \mathrm{a}$ \\
\hline \multicolumn{6}{|l|}{ Mixing ratios (MR) } \\
\hline Sole Vetch (MR1) & $168.7 \mathrm{a}$ & $8.02 \mathrm{a}$ & $20.97 \mathrm{a}$ & $5129 \mathrm{c}$ & $1075.1 \mathrm{~b}$ \\
\hline Sole Barley (MR2) & $139.3 \mathrm{c}$ & $7.38 \mathrm{c}$ & $13.29 \mathrm{c}$ & $9820 \mathrm{~b}$ & $1301.0 \mathrm{~b}$ \\
\hline $20 \%$ additive vetch to barley (MR3) & $144.6 \mathrm{bc}$ & $7.50 \mathrm{c}$ & $15.80 \mathrm{~b}$ & $10400 \mathrm{ab}$ & $1644.1 \mathrm{a}$ \\
\hline $40 \%$ additive vetch to barley (MR4) & $142.4 \mathrm{c}$ & $7.58 \mathrm{bc}$ & $16.57 \mathrm{~b}$ & $11189 \mathrm{a}$ & $1844.6 \mathrm{a}$ \\
\hline $60 \%$ additive vetch to barley (MR5) & $150.9 \mathrm{~b}$ & $7.49 \mathrm{c}$ & $15.76 \mathrm{~b}$ & $11214 \mathrm{a}$ & $1781.3 \mathrm{a}$ \\
\hline $25 \%$ vetch and $75 \%$ barley (MR6) & $160.9 \mathrm{a}$ & $7.76 \mathrm{~b}$ & $16.25 \mathrm{~b}$ & $10275 \mathrm{~b}$ & $1680.8 \mathrm{a}$ \\
\hline \multicolumn{6}{|l|}{$\mathbf{B P} * \mathbf{M R}$} \\
\hline $\mathrm{BP} 1 * \mathrm{MR} 1$ & $165.6 \mathrm{a}$ & $8.10 \mathrm{a}$ & $21.20 \mathrm{a}$ & $4956 \mathrm{~g}$ & $1051.8 \mathrm{f}$ \\
\hline $\mathrm{BP} 1 * \mathrm{MR} 2$ & $134.2 \mathrm{~d}$ & $7.45 \mathrm{def}$ & $13.68 \mathrm{de}$ & 9753 ef & 1416.0 cde \\
\hline $\mathrm{BP} 1 * \mathrm{MR} 3$ & $141.3 \mathrm{~cd}$ & $7.40 \mathrm{def}$ & $15.46 \mathrm{bcd}$ & 9911 def & $1534.4 \mathrm{~cd}$ \\
\hline $\mathrm{BP} 1 * \mathrm{MR} 4$ & $139.8 \mathrm{~cd}$ & 7.51 cdef & $16.26 \mathrm{bc}$ & 10322 cdef & $1665.8 \mathrm{bc}$ \\
\hline $\mathrm{BP} 1 * \mathrm{MR} 5$ & $148.5 \mathrm{bc}$ & 7.62 cde & $15.70 \mathrm{bcd}$ & $10917 \mathrm{bcd}$ & $1710.1 \mathrm{bc}$ \\
\hline $\mathrm{BP} 1 * \mathrm{MR} 6$ & $168.4 \mathrm{a}$ & $7.77 \mathrm{bc}$ & $17.53 \mathrm{bc}$ & $9494 \mathrm{f}$ & $1668.6 \mathrm{bc}$ \\
\hline $\mathrm{BP} 2 * \mathrm{MR} 1$ & $171.9 \mathrm{a}$ & $7.94 \mathrm{ab}$ & $20.74 \mathrm{a}$ & $5303 \mathrm{~g}$ & $1098.3 \mathrm{f}$ \\
\hline $\mathrm{BP} 2 * \mathrm{MR} 2$ & $144.4 \mathrm{bcd}$ & $7.31 \mathrm{f}$ & $12.89 \mathrm{e}$ & 9889 def & $1268.0 \mathrm{def}$ \\
\hline $\mathrm{BP} 2 * \mathrm{MR} 3$ & $148.0 \mathrm{bc}$ & $7.59 \mathrm{cde}$ & $16.14 \mathrm{bc}$ & 10889 bcde & $1753.7 \mathrm{abc}$ \\
\hline $\mathrm{BP} 2 * \mathrm{MR} 4$ & $145.0 \mathrm{bcd}$ & $7.65 \mathrm{~cd}$ & $16.88 \mathrm{bc}$ & $12055 \mathrm{a}$ & $2078.5 \mathrm{a}$ \\
\hline $\mathrm{BP} 2 * \mathrm{MR} 5$ & $153.4 \mathrm{~b}$ & 7.35 ef & $15.82 \mathrm{bcd}$ & $11511 \mathrm{ab}$ & $1964.1 \mathrm{ab}$ \\
\hline $\mathrm{BP} 2 * \mathrm{MR} 6$ & $153.2 \mathrm{~b}$ & $7.75 \mathrm{bc}$ & $14.98 \mathrm{cde}$ & $11055 \mathrm{abc}$ & $1693.0 \mathrm{bc}$ \\
\hline
\end{tabular}

*Values within a column followed by the same letter are not significantly different at LSD $(\mathrm{P} \leq 0.05)$

\section{Net energy for lactation $\left(N E_{l}\right)$}

Our results showed that orthogonal, year and mixing ratios had significant effect on $\mathrm{NE}_{1}$ (Table 2). Additive mixing ratios had more $\mathrm{NE}_{1}$ than substitutive mixing ratio. Among mixture ratios, the highest $\mathrm{NE}_{1}$ was obtained from sole vetch averaged $8.02 \mathrm{mgcal}^{-h^{-1}}$ (Table 4). These results are similar to the results of other researchers who reported that sole common vetch had highest $\mathrm{NE}_{1}$ (Yilmaz et al., 2015). On the other hand, Lauriault and Kirksey (2004) found that mixtures of pea with rye and barley had no effect on $\mathrm{NE}_{1}$. 


\section{Crude protein $(\mathrm{CP})$}

Crude protein content of produced forage is one of the most important criteria to measure forage quality (Assefa and Ledin, 2001). Therefore, concerning the relative low protein content of cereals (Mpairwe et al., 2002) and animal requirements for balanced feed, the importance of mixed cereal-legume cropping would increasingly appear to supply a nutritional diet (Lanyasunya et al., 2007). The results evidently showed that the mixture ratios had effect on crude protein and Monoculture common vetch had the highest CP content (average of 20.97\%) and sole barley had the lowest CP content (Table 4). In our results in all mixtures, the $\mathrm{CP}$ content increased as common vetch seeding proportion increased (Table 4). These results are in agreement with those reported by Giacomini et al. (2003). Also, Lithourgidis et al. (2006) reported that crude protein values of mixed of cereals with common vetch (Vicia sativa L.) had higher amount than the cereal monocultures. Similar to our results, Osman and Osman (1982) also found the highest and the lowest crude protein percentage in legume and cereal sole cropping, respectively and as legume ratio increased in mixture, protein`s percentage of mixture forage was improved.

\section{Forage yield}

Application of bed planting significantly increased $(\mathrm{P}<0.05)$ forage yield. Rice bran as bed planting treatments (BP2) had higher forage yield than without rice bran (BP1). Kusmiyati et al (2015) reported that the effect of bed planting significantly increased plant growth and forage yield of guinea grass.

According to the results, among mixing ratios, the highest forage yield was obtained from $40 \%$ additive vetch to barley with the average value of $1844 \mathrm{~kg} \mathrm{ha}^{-1}$ that it was not significantly other mixture ratio treatments (Table 4). Also, the lowest forage production was harvested from sole vetch with the average value of $1075 \mathrm{~kg} \mathrm{ha}^{-1}$ (Table 4). In average of two years, Forage yield showed significant difference among mixing ratios. The highest yield was obtained with $40 \%$ additive vetch to barley and sole cropping of vetch produced the lowest yield. Agegnehu et al. (2008) reported that additive mix cropping increased forage yield between $3 \%$ to $22 \%$ over sole cropping.

\section{Crude protein yield (CPY)}

Crude protein yield is a measure that relates $\mathrm{CP}$ concentration to the dry matter yield per unit area and gives a better estimate of total CP available in the season. One of the main advantages of legume-cereal forage intercrops has been increased protein yield, relative to cereal sole crops (Aasen et al., 2004; Carr et al., 2004). There was a significant effect for protein yield by years (Table 3) from $40 \%$ additive vetch to barley with the average value of $1844 \mathrm{~kg} \mathrm{ha}^{-1}$ that it was not significantly other mixture ratio treatments (Table 4). Also, the lowest forage production was harvested from sole vetch with the average value of $1075 \mathrm{~kg} \mathrm{ha}^{-1}$ (Table 4). The maximum crude protein yields of $2078.5 \mathrm{~kg} \mathrm{ha}^{-1}$ were obtained from rice bran as bed planting and $40 \%$ additive vetch to barley and the minimum of protein yield of forage obtained from sole vetch with both of BP1 and BP2 (Table 4). These results suggest that relying on sole vetch as a source of on-farm protein is not sufficient to satisfy the farmers' need. It could be concluded that planting of sole vetch might reduce the total forage yield but will increase the overall crude protein yield of the forage which is a more desirable feed for animals. 
Carr et al (1998) noted that increasing intercrop protein yield required a significant proportion of legume DM in the intercrop mixture. Crude protein yield of forage is one of the main criteria for forage quality. In all mixtures, an increase in the rate of vetch resulted in higher crude protein yield (Karagic et al., 2011). This was expected since legume establishment was greatly enhanced by the barley support, resulting in a higher protein-rich legume proportion in the mixture. An increase in the rate of dry matter and crude protein content apparently resulted to the increase in the rate of vetch in the mixtures. Strydhorst et al (2008) reported that barley intercrops with legumes improve forage quality compared to pure stand barley. Furthermore, lupin-barley, faba beanbarley, and pea-barley intercroppings had higher protein yield compared to pure barley.

\section{Land equivalent ratio (LER)}

The LERs in all mixed treatments were more than one (Table 5). Between additive and replacement ratios, the highest LER was belonged to additive ratio (Table 5). Results, showed that rice bran as bed planting, had better LER than without rice bran treatments (Table 5).

Table 5. LER and MAI measured for mixing ratios and bed planting of vetch and barley in two years

\begin{tabular}{|c|c|c|}
\hline Orthogonal & LER & MAI \\
\hline Additive ratio & 1.62 & 340.6 \\
\hline Replacement ratio & 1.52 & 281.2 \\
\hline \multicolumn{3}{|l|}{ Bed planting (BP) } \\
\hline Without rice bran (control) (BP1) & 1.57 & 291.2 \\
\hline Rice bran bed planting (BP2) & 1.67 & 369.8 \\
\hline \multicolumn{3}{|l|}{ Mixing ratios (MR) } \\
\hline $20 \%($ MR1) & 1.54 & 280.6 \\
\hline $40 \%$ (MR2) & 1.66 & 362.2 \\
\hline $60 \%$ (MR3) & 1.66 & 378.9 \\
\hline 25 vetch and $75 \%$ barley (MR4) & 1.52 & 281.2 \\
\hline \multicolumn{3}{|l|}{$\mathbf{B P} * \mathbf{M R}$} \\
\hline $\mathrm{BP} 1 * \mathrm{MR} 1$ & 1.51 & 256.0 \\
\hline $\mathrm{BP} 1 * \mathrm{MR} 2$ & 1.57 & 305.5 \\
\hline $\mathrm{BP} 1 * \mathrm{MR} 3$ & 1.66 & 369.3 \\
\hline $\mathrm{BP} 1 * \mathrm{MR} 4$ & 1.44 & 233.9 \\
\hline $\mathrm{BP} 2 * \mathrm{MR} 1$ & 1.58 & 305.4 \\
\hline $\mathrm{BP} 2 * \mathrm{MR} 2$ & 1.75 & 419.4 \\
\hline $\mathrm{BP} 2 * \mathrm{MR} 3$ & 1.66 & 422.5 \\
\hline $\mathrm{BP} 2 * \mathrm{MR} 4$ & 1.60 & 332.0 \\
\hline
\end{tabular}

The highest LERs of dry forage production were obtained with mixed cropping $40 \%$ and $60 \%$ additive vetch to barley, which means $66 \%$ more land were needed in sole cropping. The lowest yield-LER and was belonged to 25:75 vetch-barley ratio.

Land Equivalent Ratio (LER) was used to assess profitability of mixtures relative to sole cropping of two crops in respect of dry forage). LERs of $>1$ were obtained in all 
mixed treatments, showing higher advantage and land use efficiency in mixed compared with sole cropping. For most mixtures, the LER values of vetch were below 0.5 , indicating that vetch has disadvantages in terms of land use efficiency (Rakeih et al., 2010). In our study, land use efficiency appeared to be higher in common vetch. This could be explained by the fact that Hungarian vetch is more sensitive to warm climate conditions, which affects its competitiveness with barley in terms of land use efficiency. Similar results were reported for legume-cereal intercropping (Hauggaard-Nielsen et al., 2006; Dhima et al., 2007; Y1lmaz et al., 2015). These results again confirm that mixed cropping generally produce more yield per area than its related pure stands (Park et al., 2002). Similar reports on yield enhancement from intercropping of legumenonlegume crops have been reported (Banik et al., 2006; Ghosh, 2006; Agegnehu et al., 2006; Vasilakoglu and Dhima, 2008).

\section{Monetary advantage index (MAI)}

Results showed that additive ratios had higher MAI (Table 5). The highest MAI (422.5) was obtained in the BP2:MR3, which implied that the planting pattern was highly economical and advantageous for the mixtures. Dhima et al (2007) reported that if LER value was higher, then there was an economic benefit expressed with MAI values such as obtained in the present study.

\section{Conclusions}

Mix cropping is an important practice in the North of Iran and is considered as part of the subsistence farming designed to meet increase domestic food requirements and investigations to finding a better bed planting that is important to find better production. The results of this study clearly indicate that mixing vetch with barley and bed planting affected on the forage yield and quality. The greater benefit for forage quality was found when common vetch was grown in a monoculture or in mixtures with barley. The results indicated that usage of rice bran as bed planting had better effect on some quantity and quality of hay and mixture of common vetch with barley at the 40 and $60 \%$ additive vetch to barley gave higher forage yield and crude protein yield of all mixtures is higher than monoculture and can recommended in the North of Iran. Moreover, further studies are required to validate the positive role of other legumes in mixture with barley and to more comprehensively elucidate the effects of other bed planting on plants and their nutritional quality.

Acknowledgements. The authors would like to thank the Islamic Azad University, branch Gorgan, Iran for funding this research work.

\section{REFERENCES}

[1] Aasen, A., Baron, V. S., Clayton, G. W., Dick, A. C., McCartney, D. H. (2004): Swath grazing potential of spring cereals, field pea and mixtures with other species. - Canadian Journal of Plant Science 84(4): 1051-1058.

[2] Agegnehu, G., Ghizam, A., Sinebo, W. (2006): Yield performance and land-use efficiency of barley and faba bean mixed cropping in Ethiopian highlands. - European Journal of Agronomy 25: 202-207. 
[3] Agegnehu, G., Ghizam, A., Sinebo, W. (2008): Yield potential and land-use efficiency of wheat and faba bean mixed intercropping. - Agronomy for Sustainable Development 28: 257-263.

[4] Albayrak, S., M. Turk, O. Yuksel, Y1lmaz, M. (2011): Forage yield and the quality of perennial legume- grass mixtures under rainfed conditions. - Notulae Botanicae Horti Agrobotanica Cluj-Napoca 39: 114-118.

[5] Alizadeh, K., Teixeira da silva, J. A. (2013): Mixed cropping of annual feed legumes with barley improves feed quantity and crude protein content under dry-land conditions. Maejo International Journal of Science and Technology 7(1): 42-47.

[6] Assefa, G., Ledin, I. (2001): Effect of variety, soil type and fertilizer on the establishment, growth, forage yield, quality and voluntary intake by cattle of oats and vetches cultivated in pure stands and mixtures. - Animal Feed Science and Technology 92: 95-111.

[7] Banik, P., Sasmal, T., Ghosal, P. K., Bagchi, D. K. (2000): Evaluation of mustard (Brassica campestris var. Toria) and legume in 1:1 and 2:1 replacement series system. Journal of Agronomy and Crop Science 185: 9-14.

[8] Caballero, R., Goicoechea, E. L. Hernaiz, P. J. (1995): Forage yields and quality of common vetch and oat sown at varying seeding ratios and seeding rates of vetch. - Field Crops Research 41(2): 135-140.

[9] Carr, P. M., Martin, G. B. Caton, J. S., Poland, W. W. (1998): Forage that intercropping cereal with legume showed decreases and yield of barley-pea and oat-pea intercrops. Agronomy Journal 90: 79-84.

[10] Carr, P. M., Horsley, R. D., Poland, W. W. (2004): Barley, oat, and cereal-pea mixtures as dryland forages in the northern great plains. - Agronomy Journal 96: 677-684.

[11] Ciftci, V., Ulker, M. (2005): Effect of mixed cropping lentil with wheat and barley at different seeding ratios. - Journal of Agronomy 4(1): 1-4.

[12] Dahmardeh, M, Ghanbari, A., Syasar, B. Ramroudi, M. (2009): Effect of intercropping maize with cow pea on green forage yield and quality evaluation. - Asian Journal of Plant Science 4(2): 1-5.

[13] Daniel, J., Phillips, A., Northup, B. K. (2006): Influence of summer management practices on grazed wheat pastures on run-off. Sediment and nutrient losses. - American Society of Agricultural Engineers Journal 49: 349-355.

[14] Dhima, K. V., Lithourgidis, A. S., Vasilakoglou, I. B. (2007): Competition indices of common vetch and cereal intercrops in two seeding ratio. - Field Crop Research 100: 249-256.

[15] Ghosh, P. K. (2004): Growth, yield, competition and economics of groundnut/cereal fodder intercropping systems in the semi-arid tropics of India. - Field Crops Research 88: 227-237.

[16] Giacomini, S. J., Vendruseolo, E. R. O., Cubilla, M., Nicoloso, R. S., Fries, M. R. (2003): Dry matter, $\mathrm{C} / \mathrm{N}$ ratio and nitrogen, phosphorus and potassium accumulation in mixed soil cover crops in Southern Brazil. - Rev. Bras. Ciencia Solo 27: 325-334.

[17] Habibi, H., Kashani, A., Paknejad, F., Jafary, H., Jami Al-Ahmadi, M., Tookalloo, M. R., Lamei, J. (2010): Evaluation of hairy vetch (Vicia villosan Roth) in pure and mixed cropping with barley (Hordeum vulgare L.) to determine the best combination of legume and cereal for forage production. - American Journal of Agricultural and Biological Sciences 5(2): 169-176.

[18] Hauggaard-Nielsen, H., Andersen, M. K., Jørnsgard, B., Jensen, E. S. (2006): Density and relative frequency effects on competitive interactions and resource use in pea-barley intercrops. - Field Crops Research 95: 256-267.

[19] Horrocks, R. D., Vallentine, J. F. (1999): Harvested Forages. - Academic Press, London.

[20] Jafari, A., Connolly, V., Frolich, A., Walsh. E. K. (2003): A note on estimation of quality in perennial ryegrass by near infrared spectroscopy. - Irish Journal of Agricultural and Food Research 42: 293-299. 
[21] Karagic, D., Vasiljevic, S., Katic, S., Mikic, A, Milic, D., Milosevic, B., Dusanic, N. (2011): Yield and quality of winter common vetch (Vicia sativa L.) haylage depending on sowing method. - Biotechnol Anim Husbandry 27: 1585-1594.

[22] Kocer, A., Albayrak, S. (2012): Determination of forage yield and quality of pea (Pisum sativum L.) mixtures with pea. - Turkish Journal of Crops 17(1): 96-99.

[23] Kusmiyati, F., Sumaronso, K., Pangestu, E. (2013): Effect of mulch and mixed cropping grass-legume at saline soil on growth, forage yield and nutritional quality of guinea grass. - Journal of the Indonesian Tropical Animal Agriculture 38(1): 72-78.

[24] Lanyasunya, Z. T. P., Wang, H. R., Ayako, W. O., Kuria, D. M. (2007): Effect of age at harvest and manure or fertilizer application on quality of Vicia villosa Roth. Agricultural Journal 2: 641-645.

[25] Lauriault, L. M., Kirksey, R. E. (2004): Yield and nutritive value of irrigated winter cereal forage grass-legume intercrops in the southern high plain, USA. - Agronomy Journal 96: 352-358.

[26] Lithourgidis, A. S., Vasilakoglou, I. B., Dhima, K. V., Dordas, C. A, Yiakoulaki, M. D. (2006): Forage yield and quality of common vetch mixtures with oat and triticale in two seeding ratios. - Field Crops Research 99: 106-113.

[27] Mead, R., Willey, R. W. (1980): The concept of land equivalent ratio and advantages in yields from intercropping. - American Journal of Experimental Agriculture 16: 217-228.

[28] MeVay, K. A., Radeliffe, D. E., Hargrove, W. L. (1989): Winter legume effects on soil properties and nitrogen fertilizer requirements. - Soil Science 53: 1856-1862.

[29] Mpairwe, D. R., Sabiiti, E. N. Ummuna, N. N. Tegegne, A., Osuji, P. (2002): Effect of intercropping cereal crops with forage legumes and source of nutrients on cereal grain yield and fodder dry matter yields. - African Crop Science Journal 10: 81-97.

[30] Osman, A. E., Osman, A. M. (1982): Performance of mixture of cereal and legume forages under irrigation in the Sudan. - Journal of Agriculture Science Cambridge 98: 1721.

[31] Park, S. E., Benjamin, L. R., Watkinson, A. R. (2002): Comparing biological productivity in cropping systems: A comparing biological productivity in cropping systems: A competition approach. - Journal of Applied Economics 39: 416-426.

[32] Rakeih, N., Kayyal, H., Larbi, A., Habib, N. (2010): Forage yield and competition indices of triticale and barley mixed intercropping with common vetch and grasspea in the Mediterranean region. - Jordan Journal of Agricultural Science 6: 194-207.

[33] Ramos, M. E., Altieri, M. A., Garcia, P. A., Robles, A. B. (2011): Oat and oat-vetch as rainfed fodder cover crops in semiarid environments: Effects of fertilization and harvest time on forage yield and quality. - Journal of Sustainable Agriculture 35: 726-744.

[34] Rao, S. C., Northup, B. K., Mayeux, H. S. (2005): Candidate cool season legumes for filling forage deficit periods in the southern Great Plains. - Crop Science 45: 1973-1977.

[35] Rasmussen, J., Eriksen, J., Jensen, E. S., Esbensen, K. H., Hogh-Jensen, H. (2007): In situ carbon and nitrogen dynamics in ryegras s clover mixtures: Transfers, deposition and leaching. - Soil Biol. Biochem. 39: 804-815.

[36] Sadeghpour, A., Jahanzad, E., Lithourgidis, A., Hashemi, M., Esmaieli, A., Hosseini, M. (2014): Forage yield and quality of barley-annual medic intercrops in semi-arid environments. - International Journal of Plant Production 8(1): 77-90.

[37] Sarkar, S., Singh, S. R. (2007): Interactive effect of tillage depth and mulch on soil temperature, productivity and water use pattern of rainfed barley (Hordeum vulgare L.). Soil and Tillage Research 92: 79-86.

[38] Strydhorst, S. M., King, J. R., Lopetinsky, K. J., Neil-Harker, K. (2008): Forage potential of intercropping barley with faba bean, lupine or field bean. - Agronomy Journal 100: 182-190.

[39] Van Dyke, N. J., Anderson, P. M. (2002): Interpreting a Forage Analysis. - Alabama Cooperative Extension. Circular ANR-890. 
[40] Van Soest, P. J. (1996): Allometry and ecology of feeding behavior and digestive capacity in herbivores: a review. - Zoo Biology 15: 455-479.

[41] Vasilakoglou, I., Dhima, K. (2008): Forage yield and competition indices of berseem clover intercropped with barley. - Agronomy Journal 100: 1749-1756.

[42] Weigelt, A., Jolliffe, P. (2003): Indices of plant competition. - Journal of Ecology 91: 707-720.

[43] Yilmaz, S., Ozel, A., Atak, M., Erayman, M. (2015): Effects of seeding rates on competition indices of barley and vetch intercropping systems in the Eastern Mediterranean. - Turkish Journal of Agriculture and Forestry 39: 135-143. 